\title{
Het opleidingsfonds: een zegen!
}

\author{
C.D. de Kroon
}

\section{Samenvatting}

Het Opleidingsfonds, in 2007 opgericht om onder andere de medische vervolgopleidingen te financieren, is voor artsen in opleiding tot specialist (aios) een enorme kans meer grip te krijgen op de inhoud van hun opleiding. Instellingen en opleiders kunnen zich profileren met de opleiding omdat er nu geoormerkt geld beschikbaar is voor het opleiden van medisch specialisten. Dit artikel schetst de voordelen en kansen van het Opleidingsfonds. (Kroon CD de. Het opleidingsfonds: een zegen! Tijdschrift voor Medisch Onderwijs 2008;27(6):310-312.)

\section{Inleiding}

Het opleiden van medisch specialisten kost geld. Veel geld. Het gaat daarbij niet zozeer om het salaris van de arts in opleiding tot specialist (aios), maar om de kosten van het 'opleiden'. Vooral de tijd die de opleiders besteden aan het opleiden (supervisie, beoordelingsgesprekken, besprekingen en onderwijs geven) en de 'vertragingstijd' (de extra tijd die de aios nodig heeft per patiënt; niet alleen op de polikliniek maar ook en vooral in de behandelen operatiekamer) kosten geld. Veel geld. Onbegrijpelijk, maar tot de komst van het Opleidingsfonds in 2007 was er geen directe vergoeding voor de opleidingskosten van medisch specialisten.

\section{Het Opleidingsfonds}

Per aios krijgt het ziekenhuis een bepaald bedrag uitgekeerd. De hoogte van dat bedrag is afhankelijk van het aantal aios dat in het ziekenhuis opgeleid wordt. Momenteel wordt onderzocht of de hoogte van het bedrag ook afhankelijk zou moeten (kunnen?) zijn van bijvoorbeeld het opleidingsjaar en het specialisme waarvoor de aios wordt opgeleid. Het Opleidingsfonds is gevuld met het geld dat de zorgverzekeraars, voordat het Opleidings- fonds bestond, indirect ter beschikking stelden aan de instellingen die medisch specialisten opleiden. ${ }^{1}$ Kortom: het geld is uit de zorgbudgetten van de ziekenhuizen gehaald en vervolgens weer teruggekeerd in het opleidingsbudget van diezelfde ziekenhuizen. Dat lijkt een 'broekzak-vestzak'-constructie of een 'sigaar uit eigen doos'. Voor de financiële mannen van de ziekenhuizen is dat misschien zo, voor de aios is het Opleidingsfonds echter een zegen! Een grote zegen.

Doordat er nu daadwerkelijk betaald wordt voor het opleiden van aios moet men, als opleider en instelling, wel de inspanning leveren die vergoed wordt. Men moet, met andere woorden, de supervisie, het onderwijs en de faciliteiten leveren waarvoor men betaald wordt. Bovendien kan de aios aanspraak maken op die supervisie en het onderwijs: de opleider wordt er immers voor betaald! Hetzelfde geldt voor de extra tijd die de aios nodig heeft om een bepaalde operatie te verrichten. De opleider die het, met het oog op de klok en de operatieassistentes, maar snel zelf doet: dat is verleden tijd. De vergoeding uit het Opleidingsfonds voorziet immers óók in de vergoeding van de 'vertraging'. 


\section{Persoonlijk Ontwikkelplan}

Centraal in de modernisering van de opleiding tot medisch specialist staat het Persoonlijk Ontwikkelplan (POP). In een POP wordt aan de hand van het opleidingsplan, de ontwikkeling van de aios en de mogelijkheden in de kliniek, het verloop van de opleiding beschreven en vastgelegd. Met andere woorden: hierin wordt aangegeven waar de komende tijd het focus (welk onderdeel van het vak maar óók welke competentie) zal liggen. De nieuwe wijze van financiering van de opleiding, die ertoe leidt dat de aios niet meer zijn eigen opleiding hoeft te 'verdienen' met het leveren van productie, staat het implementeren van POP's niet meer in de weg. Daarmee zijn we weer een stap dichter bij een moderne opleiding waarin de aios aan het roer staat van zijn/haar eigen opleiding. ${ }^{2}$ Zelfs korte stages in een andere kliniek zouden (in elk geval in theorie) geen probleem moeten zijn omdat de vergoeding van het Opleidingsfonds wordt verstrekt aan degene en de instelling die daadwerkelijk de inspanning leveren.

\section{Kwaliteitsprikkel}

Tot slot, en misschien wel vooral, kan het Opleidingsfonds een goede prikkel zijn voor de bevordering van de kwaliteit van de opleiding. Zo kan de aios, wijzend op de flinke vergoeding uit het Opleidingsfonds 'waar voor zijn/haar geld eisen'. Maar vooral kunnen ziekenhuizen en maatschappen de opleiding tot medisch specialist tot speerpunt maken en zorgen voor kwaliteit. De economen die het Opleidingsfonds beheren zullen in de toekomst ongetwijfeld kwaliteit gaan belonen. Hoe die beloning eruit zal zien (meer aios of een hogere vergoeding per aios) en hoe de kwaliteit zal worden gemeten (visitaties? Gemoderniseerde PHEEM? En waarom hebben de instellingen eigenlijk niet zelf al lang geleden een instrument ontwikkeld?) is nog niet duidelijk, maar dat er veel geld verdiend kan worden met het verzorgen van een goede opleiding tot medisch specialist is duidelijk. Per slot van rekening is het Opleidingsfonds de enige post op de begroting van het ministerie van VWS waar de afgelopen jaren niet op is bezuinigd! 3

\section{Tenslotte}

Ik kan de financiële consequenties van het Opleidingsfonds op instellingsniveau niet beoordelen maar schrik natuurlijk ook van de 'horror stories' die onlangs werden gepubliceerd ('dan nemen we dus gewoon geen vrouwen meer aan'). ${ }^{4}$ Dit soort onvolkomenheden in de regelgeving moeten snel worden opgelost. Ze doen echter niets af aan het gedachtegoed van het Opleidingsfonds dat er eindelijk geoormerkt geld beschikbaar is voor de inspanning die geleverd wordt voor het opleiden van medisch specialisten. In die zin is het Opleidingsfonds een zegen voor aios én opleiders!

\section{Literatuur}

1. http://www.minvws.nl/dossiers/opleidingsfonds/ [bezocht op 8 september 2008].

2. Teunissen PW, Boor K, Scheele F, Kroon CD de, Diemen JAAM van, Vreede I de. AIOS aan het roer; laat AIOS zelf hun opleiding inkopen. Med Contact 2007: 62;38:1548-50.

3. http://www.rijksbegroting.nl/2008/begrotingsvoorstel_behandeling/begroting,kst108439b_4.ht $\mathrm{ml}$ [bezocht op 8 september 2008].

4. Raad KB de. Vrouwen en Belgen zijn de dupe. Med Contact 2008:63;29-30:1273-75.

De auteur:

Dr. C.D. de Kroon, aios gynaecologie en verloskunde, lid In VIVO-projectteam.

Correspondentieadres:

Dr. C.D. de Kroon, Leids Universitair Medisch Centrum, afdeling gynaecologie, Albinusdreef 2, postbus 9700, 2300 RC, Leiden.E-mail: cordekroon@lumc.nl 
Belangenconflict: geen gemeld

Financiële ondersteuning: geen gemeld

\section{Summary}

The 'Education Fund' was established in 2007 among other things to finance postgraduate medical education. It offers a huge opportunity for trainees to take charge of both content and organization of their training. Hospitals and consultants responsible for training can use the available funds to increase the quality of training in their institutions. This article summarises the benefits and opportunities presented by the 'Education Fund'. (Kroon CD de. The 'Education Fund': a blessing! Dutch Journal of Medical Education 2008;27(6)310-312.) 